\title{
PLANOVI I PROGRAMI FIZIČKOG VASPITANJA U PROCESU OBUKE U JNA U PERIODU 1945-1950. GODINE
}

\author{
Saša M. Vajić \\ Univerzitet odbrane u Beogradu, Vojna akademija, Katedra za fizičku \\ kulturu \\ Rade Ž. Stefanović \\ Univerzitet u Leposaviću, Fakultet sporta i fizičkog vaspitanja \\ Violeta Lj. Siljak** \\ Univerzitet UN za mir, Evropski centar za mir i razvoj, Beograd
}

radu se daje prikaz razvoja fizičkog vaspitanja u periodu od 1945.

do 1950. godine na osnovu arhivske građe kompetentnih vojnih institucija i relevantne literature. Okviri sistema fizičkog vaspitanja u ovom periodu zavisili su od: rukovođenja procesom obuke, stručnih kadrova, nastavne literature, sadržaja obuke, materijalne baze i infrastrukture. Jugoslovenska armija je u periodu po završetku Drugog svetskog rata bila oslonjena na literaturu i sistem rada armije SSSR-a, da bi uskoro pokazala potrebu za školovanjem sopstvenog kadra i oslanjanja na sopstvene resurse. $\mathrm{Na}$ osnovu analize prikupljene arhivske građe utvrđeno je da su se u periodu postojanja JA koristili nastavni oblici fizičkog vaspitanja: jutarnje vežbanje; časovi fizičkog (telesnog) vežbanja i sportske delatnosti (sportska takmičenja i javni nastupi - sletovi, štafete, prolećni i jesenji krosevi, nedelja sportova na vodi). Istraživanje je imalo za cilj utvrđivanje načina realizacije fizičkog vaspitanja u procesu obuke u vojsci u periodu 1945-1950. godine primenom planova i programa obuke koje je propisivala Jugoslovenska armija.

Ključne reči: Jugoslovenska armija, fizičko vaspitanje, nastavni oblici, obuka, planovi i programi, razvoj

\section{Uvod}

periodu od 26. aprila do 10. maja 1942. godine u Foči $(\mathrm{BiH})$ na inicijativu maršala Tita održana je „Partizanska olimpijada“. Takođe, na predlog Vrhovnog komandanta, naređenjem od 19. aprila 1942. godine, uvedena je obavezna jutarnja gimnastika za jedinice pri Vrhovnom štabu i igranje fudbala [1]. U Foči su se organizovala takmičenja u fud-

* Dr Rade Ž. Stefanović je vanredni profesor.

** Dr Violeta Lj. Šiljak je redovni profesor. 
balu, odbojci, skoku u dalj, trčanju na 1.500 metara, šahu, a odigrana je i prva zvanična fudbalska utakmica u Narodnooslobodilačkom ratu između Vrhovnog štaba i Valjevskog bataljona (pobedio je Valjevski bataljon 6:3). Mada su se i do ovih takmičenja odvijale sportske aktivnosti u jedinicama, fizičko vaspitanje i sport su se razvijali i postajali sastavni deo života i rada boraca i starešina. Istovremeno, oslobađanjem novih teritorija, fizičko vaspitanje i sport su dobijali na masovnosti, ne samo u vojsci već i u narodu, bez obzira na teške uslove života i rada boraca i građanstva. Iste 1942. godine, Druga proleterska narodnooslobodilačka udarna brigada, organizovala je razne sportske aktivnosti, a nakon oslobođenja Pljevalja u brigadi je formiran i fudbalski klub. Postoji veliki broj sačuvanih dokumenata koji svedoče o bavljenju sportom boraca i starešina u Drugom svetskom ratu, a sportska takmičenja su organizovana između borbi, posle napornih marševa i na odmorima. Osim vojničkog vežbanja upražnjavali su se i atletika, fudbal, skijanje.

Fiskultura je zvanično uvedena u Narodnooslobodilačku vojsku Jugoslavije 8. decembra 1944. godine. Tada je Glavni štab Hrvatske (sanitetsko odeljenje) u svojim naređenjima pov. br. 941 i 942, istakao značaj vežbanja: „Pri podizanju borbene sposobnosti vojske značajnu ulogu ima telesni odgoj ljudstva. Praktičnim provođenjem tjelesnog odgoja (fiskultura) u obliku tjelovežbe, lake atletike i sporta, u znatnoj se mjeri podiže fizička okretnost i izdržljivost boraca potrebna u naporima rata. Radi toga fiskultura treba da se smatra redovnim dijelom vojne obuke. Sve vojničke starešine imaju posvetiti punu pažnju tjelesnom odgoju potčinjenog ljudstva. Radi sprovođenja ovog u život, štabovi korpusa će dodijeliti svojim sanitetskim odjeljenjima po jedno stručno lice u svojstvu referenta za fiskulturu“. [2] Odgovornost za sprovođenje fiskulture pripala je sanitetu do postavljenja fiskulturnih organa, jer se prvenstveno verovalo da je to pravi način da se uskladi fizičko vežbanje sa medicinskim propisima. Takođe, u navedenom dokumentu istaknut je značaj uvođenja sportskih referenata i propisano je uvođenje jutarnjeg vežbanja u one jedinice koje do tad to nisu učinile.

U toku Drugog svetskog rata nastao je veliki broj jedinica Narodnooslobodilačke vojske Jugoslavije (NOVJ), koje su zahtevale složenost rukovođenja i upravljanja. Od 1. marta 1945. godine, Narodnooslobodilačka vojska Jugoslavije dobija novi naziv Jugoslovenska armija (JA). U trenutku završetka Drugog svetskog rata 15. maja 1945. godine, Jugoslovenska armija je brojala oko 800.000 vojnika [3]. Organizaciona struktura JA se tada sastojala od sledećih vojnih formacija: armija (Prva, Druga, Treća i Četvrta), korpusa, divizija, brigada, Korpus narodne odbrane Jugoslavije (KNOJ), vazduhoplovstvo, mornarica i vojno-teritorijalni organi i jedinice.

Odmah po završetku Drugog svetskog rata, najviši državni organi FNR Jugoslavije ${ }^{1}$ počeli su sa pripremom organizacije i formiranja Ministarstva narodne odbrane (MNO), kao organa za neposredno rukovođenje oružanim snagama u oslobođenoj zemlji. Najpre je bilo potrebno definisati ulogu i zadatke ovog organa, pri tom imajući u vidu da u tom momentu nije bilo zakonskog osnova za donošenje dokumenata kojim bi se bliže utvrdile funkcije i sama organizacija MNO. Prvi dokument iz 1945. godine, koji je bliže odredio organizaciju MNO, bio je akt o vojno-teritorijalnoj podeli države i organizaciji vojno-teritorijalnih vlasti, gde je u prvoj tački navedeno: „Ministarstvo narodne odbrane je najviša ko-

\footnotetext{
1 1945. godine kao naslednica Kraljevine Jugoslavije nastala je Demokratska Federativna Jugoslavija (DFJ), a od 29.11.1945. godine Federativna Narodna Republika Jugoslavija (FNRJ).
} 
mandna, upravna i administrativna vojna vlast za čitavu državnu teritoriju [4]." Sledeći akt je donesen 20. jula 1945. godine od strane predsednika ministarskog saveta o utvrđivanju delokruga MNO-a i njime je rešeno pitanje funkcije i organizacije MNO. Ovim aktom dat je zadatak Generalštabu Jugoslovenske armije, odnosno komandantima rodova i načelnicima službi da razrade i pripreme funkcije svojih odeljenja, odnosno određivanje formacijskog sastava jedinica, ustanova i komandi Jugoslovenske armije. S obzirom na nedostatak jasnih kriterijuma i elemenata za izradu plana formacije u vojsci, Generalštab je 1945. godine propisao nekoliko kriterijuma (principa) prilikom formulisanja i planiranja formacije vojske. Prvi princip se odnosio na broj ljudi i mogućnost popunjavanja, kvalitet ljudi, za jedinice raspoloživa sredstva i tehnika (oružje), oprema i transportna sredstva. Drugi princip se odnosio na planiranje razvoja armije i perspektive (školovanje kadra, nabavka naoružanja i vojne opreme, upravljanje resursima). Kada su u pitanju elementi za izradu formacija, oni su se odnosili na: dužnosti, čin, usklađivanje čina i funkcije. Prilikom formiranja komandi rodova i odeljenja vodilo se računa o planiranju stepena razvoja roda-službe, planiranju upravljanja ljudskim i materijalnim resursima u skladu sa planom razvoja armije, sagledavajući i demobilizaciju ljudstva, te ukupno smanjenje vojske.

Do novembra 1945. godine, nije postojao u Generalštabu JA organ koji bi rukovodio nastavom fizičkog vaspitanja u vojsci. Sve probleme i pitanja po tom osnovu rešavalo je Nastavno odeljenje Generalštaba JA. Krajem 1945. godine, formirana je Treća (nastavna) uprava GS JA, u okviru koje je formiran Odsek za fiskulturu (XI odsek). Na ovaj način počela je sa formiranjem organizacijska struktura organa za fizičko vaspitanje u Jugoslovenskoj armiji. Prvi značajan korak na utemeljenju fizičkog vaspitanja u JA, bilo je objavljivanje prvog posleratnog Uputstva za fiskulturni rad u jedinicama, gde je posebno istaknut značaj fizičkog vaspitanja u životu i radu jedinica, odnosno istaknut je značaj vežbanja kao svakodnevna potreba vojnika i starešina [5]. Sagledavajući celokupan period potrebno je istaći da su se planovi i programi fizičkog vaspitanja često menjali, a samim tim i uticali na razvoj i realizaciju svakog nastavnog oblika pojedinačno, počev od uvođenja pa do ukidanja nekih nastavnih oblika. Jugoslovenska armija je u periodu po završetku Drugog svetskog rata bila oslonjena na literaturu i sistem armije SSSR-a, da bi uskoro pokazala potrebu za školovanjem sopstvenog kadra i oslanjanja na sopstvene resurse (osnivanje Vojnog odeljenja pri DIF-u). Izgradnjom vežbališta, terena za sportske igre i stadiona sticali su se uslovi za primenu organizovanog i sistematskog vežbanja u okviru nastavnih oblika fizičkog vaspitanja koji su se tada primenjivali u JA.

Prvi Ustav FNRJ, proglasila je skupština 31. januara 1946. godine, te je na taj način utvrđeno rukovođenje i upravljanje sistemom oružanih snaga, odnosno narodnom odbranom i Jugoslovenskom armijom. Na osnovu Ustava FNRJ, doneti su zakoni o vojnoj obavezi i službi u JA. Definisanje organizacione strukture JA utvrđeno je zakonskim propisima 1946. godine, kada je ustanovljeno da u okviru oružanih snaga postoje tri vida (takođe određeni su rodovi i službe unutar vidova): Kopnena vojska (KoV), Ratna mornarica (RM) i Ratno vazduhoplovstvo (RV). Celokupna struktura mirnodopske organizacije MNO-a u periodu 1945-1950. godine, bila je zasnovana na temeljima NOR-a, kada su nastali mnogi organi i celine u sistemu vojske, koji su kasnije dograđivani na osnovu stečenih iskustava $i$ iskustava Crvene armije. Cinjenica je da je veliki uticaj na organizacionu strukturu vojske u tom momentu i pored političkih previranja koja su usledila u periodu 1948-1953. godine, imala Armija SSSR-a. Jugoslovenska armija je dobila od sovjetske armije naoružanje i 
opremu sa pratećim uputstvima i pravilima za upotrebu. Zbog nedostatka sopstvene literature, prevedena su i korišćena stručna dokumenta i literatura (pravila, propisi), preuzeti su nastavni planovi i programi za nastavu i obuku u školama i trupi Crvene armije, a veliki broj instruktora je došao u Jugoslovensku armiju radi osposobljavanja vojnog kadra.

Jugoslovenska armija je imala veoma veliki broj fiskulturnih radnika i stručnjaka, odnosno najbolji kadar od svih tadašnjih fiskulturnih organizacija i ustanova. Veliki broj pripadnika JA je tada izabran u najveće fiskulturne civilne organe kao što su bili: Fiskulturni savez Jugoslavije, republički i lokalni fiskulturni organi - odbori. Sport je prvo počeo da se razvija u vojnim sportskim društvima: Partizan, Naša krila, Hajduk, Mornar [6]. Pored toga postojala su brojna sportska društva u armijskim oblastima, Gardi i KNOJ-u. Najveći broj vrhunskih sportista u tom periodu regrutovan je u državne reprezentacije iz redova JA: atletičari - Franjo Mihalić, Ivan Gubijan, Petar Šegedin; fudbaleri - Stjepan Bobek, Zlatko Čajkovski, Franjo Šoštarić, Marko Valok; bokser - Pavle Šovljanski; košarkaš Vilmož Loci; plivač - Boris Škanata; šahista - Svetozar Gligorić itd.

Imajući u vidu znatno bolje uslove koje je imala vojna organizacija (u odnosu na civilnu), sve lokalne i druge institucije su bile usmerene na tesnu saradnju s vojskom. Novoformirana stručna tela, odbori i organizacije iz oblasti fiskulture, obavezno su u svojim redovima imali i pripadnike vojske, kao proveren i stručan kadar u procesu stvaranja i uspostavljanja sistema fizičkog vaspitanja u ratom razrušenoj državi. Sticajem okolnosti, u Jugoslovenskoj armiji posle Drugog svetskog rata, našao se veliki broj fiskulturnih radnika i stručnjaka koji su imali veoma težak zadatak uspostavljanja sistema fizičkog vaspitanja u JA.

\section{Uvođenje fizičkog vaspitanja u vojnu obuku Jugoslovenske armije}

Po završetku Drugog svetskog rata osnovna obeležja države su bila prihvatanje i izgradnja socijalističkog društva po ugledu na SSSR, usvajanje doktrine Crvene armije za odbranu zemlje, te prelazak Jugoslovenske armije na mirnodopske uslove. Razvoj sistema fizičkog vaspitanja u vojsci u tom periodu, zasnivao se na početnim iskustvima iz procesa obuke u vojsci Kraljevine Srbije, zatim na iskustvima koja su nastala kasnije na temeljima vojne obuke u Kraljevini Jugoslavije i na osnovama borbenih iskustava iz Narodnooslobodilačkog rata 1941-1945. godine. Naređenje komandanta JA, Josipa Broza iz 1945. godine o načinu i obuci Jugoslovenske armije, sadržalo je i naređenje o organizaciji fizičkog vaspitanja u vojsci. Između ostalog Broz je naveo: „Fizičko vaspitanje razvija gipkost vojnika i omogućava im da savladaju sve teškoće", te su pripadnici Jugoslovenske armije fizičko vaspitanje uvrstili u svakodnevne obaveze, dajući im praktički značaj borbene obuke [7].

Prvo naređenje Ministarstva odbrane Demokratske Federativne Jugoslavije, koje je potpisao maršal Tito 1945. godine, dato je u petnaest tačaka i sadržalo je osnovna uputstva o načinu izvođenja i realizaciji procesa obuke u novoformiranoj Jugoslovenskoj armiji. Prva obuka realizovana je u šestomesečnom periodu, od pojedinačne obuke do zajedničkih vežbi koje su se sprovodile u armijama i divizijama. Ovo naređenje sadržalo je i određene tačke koje su se odnosile na tadašnju obuku u vojsci. U okviru druge tačke 
ovog naređenja, predloženo je da se iskoriste iskustva Crvene armije po pitanju organizacije borbene obuke i vaspitanja vojnika. U tački pet ovog naređenja, ističe se da je osnovni zadatak komandanata armija da: „organizuju materijalno obezbeđenje obuke i vežbi putem izgradnje dobro opremljenih strelišta, terenskih odseka sa savremenim utvrđenjima za taktičke vežbe, vežbališta za borbu prsa u prsa, specijalnih vežbališta za savlađivanje različitih prepreka, streljačkih naprava i pribora za obuku“. Pripadnici Jugoslovenske armije su fizičko vaspitanje uvrstili u svakodnevne obaveze, dajući im praktični značaj borbene obuke (telesno vaspitanje je naziv koji je bio u upotrebi u navedenom periodu). Ovim naređenjem maršala Tita od 05. juna 1945. godine, u tački sedam propisuje se uvođenje gimnastičkih vežbi posle ustajanja (jutarnje vežbanje) u trajanju od 20 minuta, te je bilo potrebno u tu svrhu izraditi specijalno gimnastičko uputstvo. Naredbom je bilo predviđeno da proces obuke započne 15. juna 1945. godine, u trajanju od osam časova radnim danima i subotom u trajanju od pet časova.

Ova vrsta obuke - telesno vaspitanje ili fiskultura, koja se realizovala kroz sva tri modela obuke: trupna (sa vojnicima na redovnom odsluženju vojnog roka), školska (sa pitomcima Vojnih akademija, starešinama i polaznicima drugih vojnih škola u tom periodu) i predvojnička obuka (izvodila se sa omladinom pre redovnog služenja vojnog roka). Sadržaje, oblike i kriterijume za ovu obuku propisalo je Odeljenje za opštevojna pravila Generalštaba JA. Prema Direktivi Vrhovnog komandanta, obuka vojnika i jedinica - trupna obuka trajala je deset meseci, a izvodila se svakog dana - leti osam, a zimi sedam časova. U kasnijem periodu usled naglog razvoja nauke i usavršavanja novih borbenih i savremenijih tehničkih i materijalnih sredstava, dolazilo je do čestih promena u sistemu obuke i vaspitanja.

Struktura sistema fizičkog (telesnog) vaspitanja u trupnim jedinicama, vojnim školama i učilištima Jugoslovenske armije, u periodu 1945-1950. godine, sastojala se od nastavnih oblika fizičkog vaspitanja: jutarnje vežbanje, časovi fizičkog (telesnog) vežbanja i sportske delatnosti (sportska takmičenja, sletovi, štafete, prolećni i jesenji krosevi, nedelja sportova na vodi) [8]. Ovakva struktura se zasnivala na iskustvima iz perioda pre i za vreme Narodnooslobodilačkog rata 1941-1945. godine. Neki nastavni oblici su imali svoje korene upravo u ovom periodu.

Jutarnje vežbanje se realizovalo od 1945. godine svakodnevno, sem nedelje, u trajanju od 15 minuta (od 1947. godine realizovalo se u trajanju od 20 minuta) pre doručka, po vodovima i pod rukovodstvom desetara. Na jutarnjem vežbanju izvodile su se sledeće vežbe: kretanje hodom i trčećim korakom, „zarjadka“ (ruski termin za splet vežbi oblikovanja) i elementarne igre [9]. Cilj jutarnjeg vežbanja je bio da se organizam pripremi za dnevni rad. U okviru jutarnjeg vežbanja planirani sadržaj koji se realizovao odnosio se na: kretanje osam minuta (hodanje - trčanje), vežbanje u mestu sedam minuta i pet minuta je u planu bila igra. Jutarnje vežbanje se primenjivalo u četiri varijante, u zavisnosti od perioda obuke i vremenskih uslova: prva varijanta - marševski i trčeći korak (kombinacija); druga varijanta - jutarnje vežbanje sa puškom; treća varijanta - „zarjadka“; četvrta varijanta - kretanje 12:12 (12 koraka hodom, 12 koraka trčeći - na ovaj način se prelazilo za sat vremena oko 10 kilometara).

Časovi fizičkog (telesnog vežbanja) vežbanja za vojnike u JA trajali su 40 minuta u 1945. godini. U uvodnom delu časa, u cilju zagrevanja organizma, izvođene su vežbe u kretanju hodom ili trčećim korakom, kao i vežbe oblikovanja. U glavnom delu časa 
obrađivane su sledeće teme: borba prsa u prsa, atletika, vežbe na spravama i odbojka. U završnom delu časa izvodile su se elementarne igre, a čas se završavao hodanjem uz pesmu.

Časovi fizičkog vežbanja za starešine JA nisu bili regulisani propisima, nisu bili planirani, niti su bili sistematska aktivnost. Starešine su samoinicijativno upražnjavali onu sportsku aktivnost koja im je bila dostupna u odnosu na uslove u kojima su radili. $U$ datim uslovima rada su to bile sportske igre, fudbal i odbojka, a od atletskih disciplina uglavnom su izvodili bacanje kugle i skok u dalj. Ove sportske aktivnosti starešine su upražnjavale u slobodno vreme posle radnih obaveza, međutim bilo je i primera da su se u pojedinim komandama i jedinicama starešine, uz odobrenje nadležnih, pojavljivale i izvodile jutarnje vežbanje sa vojnicima, a zatim posle vežbanja, nastavljale su da realizuju sportske igre, fudbal i odbojku.

Sportska delatnost u JA je podrazumevala dobrovoljnu sportsku aktivnost koja je bila veoma zastupljena i masovna u okviru vojne organizacije i planirana kalendarom za sportska takmičenja, definisana planovima i programima sportskih odbora u jedinicama, vojnim garnizonima i školama. Ova aktivnost je imala zadatak da pokaže sliku o fizičkom vežbanju u vojsci i pre svega da dočara uspeh postignut u okviru redovne nastave obuke; da podstakne na bavljenje fizičkim vežbanjem; da razvija timski i kolektivni duh; da razvija moralno-voljne osobine kod vojnika i starešina.

U Jugoslovenskoj armiji sportska takmičenja su bila tradicija koja se sprovodila i za vreme Drugog svetskog rata u oslobođenim teritorijama gde god su za to postojali minimalni uslovi i gde su okolnosti to dozvoljavale. Prvo učešće pripadnika Jugoslovenske armije po završetku rata bilo je 1945. godine na državnom prvenstvu u atletici i fudbalu. Organizovana sportska takmičenja u Armiji, imala su široko rasprostranjen programski sadržaj i bila su veoma razvijena u našim jedinicama. Pripadnici vojske su imali svoja takmičenja na nivou vodova, četa i bataljona, a sa tih takmičenja su se birali takmičari za svearmijska prvenstva. Osim sportova koji su bili popularni u narodu (košarka, rukomet, fudbal, atletika, itd), JA se trudila da razvije i određena sportska takmičenja koja u tom periodu nisu bila dovoljno zastupljena.

Period od formiranja Jugoslovenske armije 1945. godine, može se posmatrati kao period uspostavljanja celokupnog procesa obuke, baziranog na iskustvima Armije SSSRa. U navedenom periodu došlo je do reorganizacije ratnih formacija i stvaranja temelja, za izgradnju jakih i moćnih oružanih snaga, oslonjenih na odličnu vojnu i fizičku osposobljenost njenih pripadnika. U tom smeru je i postavljen početni sistem fizičkog vaspitanja u vojsci, kao okosnica opšte vojne obuke i osnova za nadgradnju specijalne vojne i stručne osposobljenosti.

Program nastave fizičkog vaspitanja u vojnim školama, jedinicama, komandama i učilištima u periodu postojanja JA, bio je prilagođen uslovima i mogućnostima. Program je zavisio i od stručne obrazovanosti nastavnika i njihovih predispozicija za pojedine teme iz oblasti fizičkog vaspitanja. Ovakvo stanje je potrajalo do novembra 1945. godine kada je na snagu stupio jedinstveni program fizičkog vaspitanja za Jugoslovensku armiju. Planiranje celokupne obuke zavisilo je od specifičnosti jedinice u realizaciji zadataka u sistemu vojske, odnosno od opštih i specifičnih zadataka rodova i službi u JA i vremena predviđenog za proces obuke (Tabela 1). 
Tabela 1 - Pregled izvođenja obuke u Jugoslovenskoj armiji u periodu 1945-1949. godine [10]

\begin{tabular}{|c|c|c|c|c||}
\hline \multirow{2}{*}{ Period } & \multirow{2}{*}{$\begin{array}{c}\text { Dužina } \\
\text { vojnog roka } \\
\text { (meseci) }\end{array}$} & u jedinicama rodova & $\begin{array}{c}\text { U jedinicama } \\
\text { službi }\end{array}$ & \multirow{2}{*}{ Napomena } \\
\cline { 3 - 4 } & 24 & 12 & 6 & \multirow{2}{*}{ RM i RV - 36 meseci } \\
\hline \hline $1945-1947$ & 24 & 12 & 6 & \\
\hline $1947-1949$ & 24 & &
\end{tabular}

\section{Planovi i programi fizičkog vaspitanja u Jugoslovenskoj armiji u periodu od 1945. do 1950. godine}

U prvom posleratnom Uputstvu za fiskulturni rad u jedinicama, koje je 28. septembra 1945. godine izdala Politička uprava Ministarstva narodne odbrane, istaknut je značaj masovnog bavljenja sportom, te se naglašava da fizičko vaspitanje treba da postane sastavni deo života i rada jedinica, odnosno svakodnevna praksa vojnika i starešina. $\mathrm{Na}$ osnovu izveštaja Ministarstva narodne odbrane, posebno i veoma značajno poglavlje u sportskom životu jedinica predstavljala je „dobrovoljna masovna fiskultura za koju je među vojnicima $i$ starešinama vladalo veliko interesovanje, o tom velikom interesovanju i ljubavi za fiskulturu najbolje govori dobrovoljno sakupljanje priloga u mnogim jedinicama", a te dobrovoljne priloge pripadnici JA sakupljali su kako se kaže u navedenom dokumentu "radi nabavke najnužnijih fiskulturnih sprava i rekvizita [11]."

Prvi program fiskulture u Jugoslovenskoj armiji, koji se primenjivao od novembra 1945. godine, izdao je Generalštab Jugoslovenske armije i obuhvatao je: vežbe oblikovanja (,zarjadka“), borbu prsa u prsa („rukopašni boj“), atletiku, vežbe na spravama i odbojku [12]. U dopisu uz Program sugerisano je da se u slobodno vreme organizuju takmičenja u atletici, boksu, rvanju, fudbalu, košarci i plivanju, uz napomenu da postoje uslovi za organizaciju takmičenja.

Uputstvo za organizaciju i metodsko izvođenje nastave u pešadiji iz 1945. godine, koje je propisao NGS general-lajtnant Arso Jovanović, u prvom delu, u tački dva, objašnjava šta pripadnik Kopnene vojske treba da savlada u okviru nastave u jedinicama, između ostalog napominje gimnastiku i fiskulturne vežbe, dok u trećem odeljku, u okviru radnog vremena, predviđeno je da se: časovi gimnastičkih vežbi (20 minuta), vežbe iz egzercira (radnje sa puškom - 30 minuta), obavezne vežbe iz fiskulturne nastave, ne računaju u radno vreme od osam sati [13].

Plan i program za izvođenje trupne nastave kod jedinica divizijske i pukovske artiljerije iz 1945. godine, predviđao je da se celokupna obuka izvodi svakog dana u nedelji, sem nedeljom i to sedam časova dnevno (od toga četiri časa pre podne a tri časa po podne) [14]. Ovim planom predviđena je jutarnja gimnastika (vežbanje) u trajanju od 20 minuta. U okviru jedinačne obuke nisu bili predviđeni posebno časovi fizičkog vežbanja, već se ta obuka spajala sa vojnom obukom, te se u predmetu koji se zvao pešadijski egzercir bile sadržane i vežbe sa naoružanjem i bez njega (tema kretanje: vrste kretanja, 
kretanje običnim korakom, trčećim korakom sa i bez naoružanja itd). Jedinačna obuka je trajala tri nedelje (21 kalendarski dan, 18 radnih dana, ukupno predviđenih 111 časova). Izučavala se: opšta obuka od 8 predmeta (tu je spadao egzercir) i specijalna obuka od 11 predmeta. Plan za izvođenje obuke u periodu jedinačne obuke kod jedinica pukovske artiljerije mitraljeskih četa obuhvatao je period od četiri nedelje (28 kalendarskih dana), 24 radna dana i 144 radnih časova. U okviru opšte obuke izučavalo se osam predmeta, a u specijalnoj obuci izučavalo se takođe osam predmeta. Pešadijski egzercir je obuhvatao 14 časova u četiri nedelje.

Plan i program za obuku pojedinca u pešadiji KoV-a (trajanje tri nedelje) od 05. juna 1945. godine, pod tačkom osam predviđalo je fizičko (telesno) vežbanje koje se sprovodilo u okviru jutarnjeg vežbanja, dok se ostala nastava izvodila na osnovu udžbenika Nastava za gimnastiku [15]. Obuka je trajala tri nedelje, a nastava fizičkog vaspitanja se izvodila u poslednjoj nedelji, u trajanju od deset radnih časova [16].

Početkom 1946. godine, Generalštab Jugoslovenske armije propisao je nove planove i programe obuke i vaspitanja vojnika i trupnih starešina i utvrdio je prve kriterijume materijalnog obezbeđenja nastave. $U$ to vreme, obuka i vaspitanje jedinica i komandi delila se na dva perioda: zimski i letnji. Prema tadašnjim sistematskim rešenjima, komande armija su bile ovlašćene da planove i programe obuke vojnika i trupnih starešina prilagođavaju uslovima života i rada svoje jedinice jer tada je materijalno obezbeđenje ipak bilo još uvek ispod nivoa realnih potreba.

Od 1946. godine Program fizičkog vaspitanja koji se primenjivao u pukovima gde su postojali posebni organi za rukovođenjem nastave fizičkog vaspitanja, bio je obogaćen sledećim sadržajima: atletika, vežbanje na spravama, borba prsa u prsa, savlađivanje poligona prepreka na 110 metara, borilačke vežbe iz boksa i rvanja, plivanje, odbojka, košarka $i$ elementarne igre. Usled nedostatka stručnog kadra iz oblasti fizičkog vaspitanja i nastojanja da se nastava ne pretvori u igre sa loptom, ovaj program je bio detaljno propisan i razrađen po časovima.

Plan i program borbene obuke pojedinca i desetine (odeljenja) u pešadiji iz 1946. godine obuhvatao je obuku za minobacačku, mitraljesku i izviđačku četu [17]. Od 14 predmeta, pod brojem pet, kao predmet je predviđena fiskultura i to za minobacačku i mitraljesku četu u fondu od po 78 časova, dok je za izviđačku četu bilo predviđeno 97 časova. U okviru plana i programa za fizičko vaspitanje obavezno su se izvodili kao organizacioni oblici fizičkog vaspitanja: jutarnje vežbanje i čas fizičkog vežbanja: U okviru jutarnjeg vežbanja izvodile su se vežbe oblikovanja - zarjadka, vežbe sa puškom i teretom. U okviru časova fizičkog vežbanja izvodile su se vežbe u okviru tri zadatka: borba prsa u prsa (rukopašni boj), atletika, te penjanje, preskoci zapreka i ravnoteža. Na prvi deo odlazilo je 20 časova, a za ostalo po 10 časova. Dopuna od 30 časova do punog nastavnog fonda (od 78 časova), služila je za usavršavanje i poboljšanja normi u okviru časova fizičkog vežbanja. Samo izvođenje časova fizičkog vežbanja iz ova tri zadatka realizovala su se uporedo, za prvi zadatak po dva časa odjednom (100 minuta), a za drugi i treći zadatak po jedan čas (50 minuta). Inače vežbališta su bila opremljena, tako da su se sa uspehom svi časovi realizovali. Po posebnom Uputstvu izvođena je obuka u plivanju. Nastava u plivanju je sprovođena u okviru časova fizičkog vežbanja ali fond sati nije ulazio u fond od 78 časova koji je bio predviđen za pešadiju u 1946. godini, već je ulazio u fond sati koji se predviđao kao rezervno vreme u fondu od 48 časova [18]. 
Plan i program borbene obuke lovačke avijacije iz 1946. godine u okviru fiskulture fizičke obuke predviđao je realizaciju časa fiskulture u trajanju od jednog sata [19]. Osim toga izvodilo se i svakodnevno jutarnje vežbanje u trajanju 15-20 minuta. U zavisnosti od specijalnosti u okviru vazduhoplovstva razlikovao se i realizovani fond sati fiskulture. Za osoblje koje se menjalo u vazduhoplovnom puku nastava fiskulture se realizovala u: letnjem periodu (gimnastika - 14 časova i borba prsa u prsa - 6 časova), zimskom periodu (smučarska nastava - 26 časova, gimnastika - 16 časova), jesenjem i prolećnom periodu (gimnastika - 20 časova i borba prsa u prsa - 10 časova). Sveukupno fond za fiskulturu je iznosio 92 časa. Za stalno osoblje vazduhoplovnih pukova, fond sati fiskulture iznosio je 90 časova (gimnastika - 30 časova, borba prsa u prsa - 18 časova, smučarska nastava - 30 časova i plivanje - 12 časova). Za vazduhoplovne pukove na frontu, fond sati iznosio je 120 časova (gimnastika - 40 časova, plivanje - 20 časova, borba prsa u prsa - 20 časova i smučarska nastava - 40 časova). Program je obuhvatao sadržaje iz gimnastike (vežbe na tlu i na spravama), smučarske nastave (koristio se uput za nastavu u vojsci), borbe prsa u prsa i plivanja (program za vazduhoplovne pukove i škole).

Plan i program borbene obuke jurišne avijacije iz 1946. godine, obuhvatao je istovetni program i sadržaje iz fiskulture kao za lovačku avijaciju za 1946. godinu iako je plan i program jurišne avijacije bilo posebno izdanje koje je štampalo Ministarstvo narodne odbrane Jugoslovenske armije [20].

Tokom 1947. godine sačinjen je novi Program fizičkog vaspitanja u kome je detaljno propisan i po časovima tačno razrađen sadržaj rada na svakom času [21]. Međutim i tada se osećala manjkavost u angažovanju komandi po pitanju planskog i sistematskog izvođenja nastave. Ona je najvećim delom bila prepuštena fiskulturnim rukovodiocima, dok su komande bile mnogo više angažovane oko priprema za sportska takmičenja, jer se na osnovu uspeha na tim takmičenjima i dalje cenio rad na polju fizičkog vaspitanja u tim jedinicama. Takav način nastave fizičkog vaspitanja primenjivan je sve do januara 1950. godine (uz jedinu izmenu iz 1949. godine koja se odnosila na dužinu prepreka, umesto 110 metara, staza je iznosila 150 metara i imala je 8 prepreka). Od 1949. godine, čas fizičkog vežbanja je trajao 45 minuta, a održavao se dva puta nedeljno. Od 1950. godine u okviru časova fizičkog vežbanja uvode se osnove sportskih igara (odbojka, rukomet, fudbal).

Plan i program borbene obuke zemaljske artiljerije Jugoslovenske armije iz 1947. godine, obuhvatao je: političku nastavu, opštevojnu obuku, specijalnu obuku i taktičku obuku [22]. Ukupan fond časova za specijalnosti u okviru zemaljske artiljerije u Jugoslovenskoj armiji kretao se od 1.380 časova celokupne obuke (za izviđače, poslužioce i vozače) do 1.560 časova (za računaoce, topografe, telefoniste i radiste). Fiskultura je spadala u opštevojnu obuku i imala je fond od 80 časova za sve specijalnosti u okviru zemaljske artiljerije. Osnovni zadatak obuke u tom periodu u JA, bio je jačanje organizma vojnika i podoficira i razvijanje fizičkih i psiholoških sposobnosti: snage, izdržljivosti, okretnosti, brzine, smelosti, odvažnosti, itd. Takođe, zadatak fizičke obuke bio je i razvijanje sposobnosti za rukovanjem hladnim oružjem i savladavanje prepreka (prirodnih, veštačkih i vodenih) sa pomoćnim sredstvima i bez njih. U okviru metodskih uputstava koje su dobijali izvođači fizičke obuke - oficiri, posebno je naznačeno da se fizička obuka mora povezivati sa radnjama koje su vojnici zemaljske artiljerije izvršavali u zavisnosti od svojih specijalnosti (poslužioci - nošenje tereta, prevlačenje tereta na rukama; izviđači i telefonisti - sposobnost prikrivenog kretanja na različitim terenima, izdržljivost u trčanju sa teretom 
i bez njega, kretanje četvoronoške, pognuto, puzanje, itd). Zbog ovih napomena na svakom času fiskulture - fizičke obuke odvajalo se od deset do dvanaest minuta za treniranje fizičkih sposobnosti, a u zavisnosti od specijalnosti vojnika. Planiranje nastave iz fizičke obuke vršilo se ravnomerno tokom godine - u podjednakim vremenskim razmacima kako bi vojnici imali kontinuitet u obučavanju i održavanju svojih fizičkih sposobnosti, neophodnih za redovno izvršavanje svojih zadataka. Trajanje časa fizičke obuke iznosilo je 50 minuta, ali su se neki sadržaji, poput borbe prsa u prsa, izvodili spojeno u trajanju od 100 minuta (dva nastavna časa). U okviru programa bilo je planirano i vreme za takmičenja, a discipline su se birale u zavisnosti od interesovanja vojnika. U mestima gde je bilo mogućnosti za izvođenje obuke u plivanju, izvodila se obuka neplivača, a tamo gde nisu postojali uslovi za to sprovodile su se vežbe za razvoj snage i šestoboj. Jutarnje vežbanje se realizovalo svakodnevno u trajanju od najmanje 20 , a najviše 30 minuta i u njemu su učestvovali svi vojnici i podoficiri (jutarnje vežbanje je podrazumevalo: proste vežbe, vežbe na spravama, grupne vežbe i igre, kao i trčanje i hodanje). U okviru jutarnjeg vežbanja koristila su se sledeća sredstva: vratila, razboji, konj, konopac, motke i lestve. Sadržaji koji su se realizovali u okviru fizičke obuke obuhvatali su: borbu prsa u prsa (bodovi nožem, udari kundakom, odbijanja i odbrane; načini borbe ašovčićem i ašovom; načini borbe nožem; bacanje ručnih bombi; savlađivanje prepreka i kompleksna vežbanja), gimnastika (gimnastički kompleksi), šestoboj (trčanje 100 metara, bacanje kugle $7.25 \mathrm{~kg}$, penjanje uz konopac; drugi kompleks: skok u dalj iz zaleta, bacanje bombe od $600 \mathrm{gr}$, trčanje na 1.500 metara) i plivanje (pripremne vežbe i načini plivanja; plivanje korišćenjem priručnih sredstava; uvežbavanje plivanja, ronjenja i skokova u vodu; plivanje u odelu, sa oružjem i bez njega, sa priručnim sredstvima i bez njih). Celokupna fizička obuka se delila na šest delova, tako da je sadržaj borba prsa u prsa obuhvatao 20 časova, gimnastika 27 časova, šestoboj 17 časova i plivanje 16 časova, ukupno 80 časova.

Plan i program trupne nastave za pešadiju u letnjem nastavnom periodu 1947. godine, koji je odobrio načelnik Četvrte uprave general - major Vjekoslav Klišanić, predviđala je za pešadiju KoV-a, da u okviru 916 časova celokupne obuke 54 časova bude predviđeno za fiskulturu i to za streljačke, mitraljeske i minobacačke jedinice [23]. Obuka pojedinaca je obuhvatala 20 časova, odeljenja 10 časova, voda 10 časova, čete i bataljona 14 časova.

Program nastave iz obavezne fiskulture u letnjem periodu iz 1947. godine, koji je izdao Generalštab, obuhvatao je tri teme (šestoboj, borbu prsa u prsa i plivanje) sa ukupnim fondom od 54 časa [24]. U ovaj fond sati nije uračunat fond sati za temu plivanje, odnosno za obuku neplivača koja se sprovodila kada su to vremenski uslovi zadovoljavali. Tema šestoboj obuhvatala je sledeće vežbe: trčanje na 100 metara, bacanje kugle, skok u dalj, bacanje granate, penjanje, trčanje na 1.500 metara i takmičenje u šestoboju. Tema borba prsa u prsa izvođena je kroz sledeće vežbe: borba puškom, borba kratkim oružjem i bez oružja, kretanje i savlađivanje prepreka, bacanje granate, kompleksna vežbanja, takmičenje i ocenjivanje. Tema plivanje realizovala se kroz vežbe: obuka neplivača, stilovi plivanja, načini prelaženja vodenih prepreka, skokovi u vodu, ronjenje, spasavanje davljenika. Prema ovom programu, jutarnje vežbanje u letnjem nastavnom periodu 1947. godine, izvodilo se svakog dana odmah posle ustajanja i trajalo je 20 minuta, a odvijalo se pod rukovodstvom četnih starešina. Ono je započinjalo kretanjem osam minuta (norme kretanja su bile predviđene: prva dva meseca korakom pet minuta - 500 metara, trčeći tri minuta - 500 metara; druga dva meseca korakom četiri minuta - 400 metara, tr- 
čeći četiri minuta - 700 metara; posle četiri meseca korakom tri minuta - 300 metara, trčeći pet minuta - 800 metara), vežbe u mestu sedam minuta, igra pet minuta. Raspored jutarnjeg vežbanja se izvodio po planu i po danima: ponedeljak, utorak, četvrtak i petak kretanje osam minuta prema tablici, vežbe u mestu sedam minuta, igra pet minuta. Redosled vežbi je mogao biti i promenjen: vežbanje u mestu, kretanje, igra (može se zadati vežba kretanja uz pesmu). Sredom su se radile sledeće vežbe: kretanje 12:12 do dva kilometara, dva starta na 30 metara, kretanje voljnim korakom uz pesmu. Subotom i nedeljom, na jutarnjem vežbanju su se izvodile igre i vežbe: raznoške preko vežbača, nošenje druga, terenski skokovi i kratke štafetne igre. Zatim su se radila i kretanja marševskim (hodajućim) korakom i kretanja trčećim korakom, kretanja 12:12 (marševskim i trčećim korakom), prosta vežba iz kompleksa za značku fiskulturnika (šest delova), zatim prvi kompleks gimnastičkih prostih vežbi od sedam vežbi i završna vežba.

Program borbene obuke jedinica za vezu Jugoslovenske armije iz 1948. godine, obuhvatao je fiskulturu kao deo opštevojne obuke u fondu od 80 časova u zimskom i letnjem periodu [25]. Svaki od ovih perioda je imao dva do tri razdela. Zimski period je obuhvatao ukupno 39 časova (prvi razdeo 25 časova - borba prsa u prsa 15 časova i gimnastika 10 časova; drugi razdeo 14 časova - borba prsa u prsa pet časova, gimnastika tri časa i šestoboj šest časova). Letnji period je obuhvatao 41 čas (prvi razdeo 18 časova - borba prsa u prsa sedam časova, šestoboj četiri časa i plivanje sedam časova; drugi razdeo obuhvatao je 17 časova - borba prsa u prsa četiri časa, gimnastika tri časa, šestoboj dva časa i plivanje osam časova; treći razdeo obuhvatao je čest časova (borba prsa u prsa dva časa, gimnastika dva časa i šestoboj dva časa). U okviru fiskulture - fizičke obuke, nastavu je izvodio komandir voda, a u radu su učestvovali svi vojnici i podoficiri. Cilj teme borba prsa u prsa bio je osposobljavanje vojnika za borbu hladnim oružjem i uopšte za borbu izbliza, kao i kretanje preko prirodnih i veštačkih prepreka sa pomoćnim sredstvima i bez njih. U okviru gimnastike, razvijala se brzina, elastičnost i okretnost uz savlađivanje težine vlastitog tela, podizanje fizičke kondicije za izvršavanje težih napora. Tema šestoboj je trebala kod vojnika da razvije podizanje fizičke sposobnosti kroz različite discipline i da postigne optimalan nivo kod vojnika za savladavanje određene norme predviđene u toku obuke.

U 1949. godini časovi fizičkog vežbanja (obuke) izvodili su se dva puta nedeljno po 45 minuta, realizovali su in komandiri vodova koje su pripremali pomoćnici načelnika za fiskulturu. Program koji se tada sprovodio za časove fizičkog vežbanja je sadržao: vežbe oblikovanja, atletiku, vežbe na spravama, savlađivanje staze prepreka 150 metara, borba prsa u prsa, boks, rvanje, elementarne igre, sportske igre i plivanje (ako su postojali uslovi) [26].

Gradivo (teme) za program fizičkog vežbanja do 1950. godine uzimane su iz priručnika Crvene armije koji je obuhvatao 13 predmeta za celokupnu obuku vojnika (jedan od predmeta je bio fizičko vežbanje). Iz ovog priručnika iz programa fizičkog vežbanja su preuzeti sledeće teme i načini vežbanja: zarjadka, rukopašni boj, borba prsa u prsa. Pošto je proučen program fizičkog vežbanja u američkoj, engleskoj i sovjetskoj armiji, kao i stečena vlastita iskustva kroz nastavu fizičkog vaspitanja, već u narednim godinama izvršen je izbor navedenih tema za program fizičkog vaspitanja. Radi poboljšanja fiskulturne delatnosti, a i da bi se postigli što bolji rezultati u fizičkoj kondiciji celokupnog sastava armije, vodeći računa da se ide u korak sa reorganizacijom fiskulturne delatnosti u FNRJ, sprovedena je reorganizacija fiskulturne delatnosti i u JA. Osnovni metodi rada su bili demonstracija i praktično vežbanje. Posebnom direktivom o obuci i vaspitanju, regulisano je bilo da su za nastavu 
fizičkog vaspitanja odgovorne komande jedinica, uprave škola i ustanova. One su imale cilj da realizacijom časova fizičke i vojne obuke podignu nivo fizičke sposobnosti vojnika JA. Taj zaokret je učinjen 1950. godine kada su ukinuta formacijska mesta pomoćnika načelnika za fiskulturu u komandama divizija, brigada i pukova, pa je organizacija i sprovođenje fizičke obuke u trupi preneta u nadležnost nastavnih organa koji su pored svojih redovnih dužnosti podsticali razvoj fizičkog vaspitanja u duhu dobijenih uputstava.

$U$ analizi Fiskulturnog odeljenja Generalštaba iz 1950. godine konstatovano je: „U jedinicama mnoge starešine, a naročito one starešine koje rade u višim štabovima $i$ kancelarijama, nisu posedovale potrebnu fizičku kondiciju i često su zaostajale iza naših vojnika u pogledu izdržljivosti i okretnosti, savlađivanja prepreka i drugih teškoća, što je s jedne strane znatno otežavalo mogućnosti rukovođenja jedinicom, a s druge, ovakve starešine nisu bile u stanju da prednjače ličnim primerom, u slučaju kada su se zahtevali veći napori [27]." Da bi se poboljšala fizička kondicija starešina, nakon te analize usledilo je Naređenje načelnika GŠ JA (Četvrta uprava) pov. br. 78, od 14. januara 1950. godine u kojem je naloženo da se zavede obavezna obuka iz fizičkog vežbanja za sve podoficire, vojne službenike i oficire u trupi i u komandama - ustanovama [28]. Obuka se izvodila u okviru radnog vremena jedanput nedeljno po dva časa. Bila je obavezna za sve, osim za invalide, fizički ograničeno sposobne i za one koji su zbog zdravstvenog stanja ili poznih godina života, bili oslobođeni. Odluku o oslobađanju donosile su komande (uprave) koje su organizovale obuku. Za rukovodioce i nastavnike, određivani su oni oficiri koji su za to imali najviše smisla i sposobnosti. kako bi ispravno izvodili obuku, za izvođače su organizovane instruktaže, pod rukovodstvom fiskulturnih organa. Program i uputstvo za izvođenje fizičke obuke, koje je izradilo Odeljenje za fiskulturu Generalštaba JA, obuhvatalo je sledeće discipline: savlađivanje bojnih prepreka, gimnastiku, atletiku, sportske igre, borilačke sportove, smučanje (zimi) i plivanje (leti) [29]. Poslednje dve discipline su bile predviđene za realizaciju, tamo gde su za to postojale materijalne mogućnosti i atmosferski uslovi. Treba napomenuti da oficiri sa kojima je izvođena obuka u jahanju nisu imali obuku iz fizičkog vežbanja. Karakteristično je da se u tom Naređenju, naglašava potreba za razvijanjem široke sportske aktivnosti starešina uključivanjem u razne discipline masovnog fizičkog vaspitanja, te da se njima bave prema individualnim sposobnostima i naklonostima. Preporučene su discipline: streljaštvo, atletika, tenis, mačevanje, odbojka itd.

\section{Kadrovi i rukovođenje u oblasti fizičkog vaspitanja u Jugo- slovenskoj armiji u periodu od 1945. do 1950. godine}

U Jugoslovenskoj armiji, u prvim posleratnim godinama (1945-1947), velika pažnja se posvećivala školovanju i usavršavanju stručnih kadrova u oblasti fizičke kulture. Krajem septembra 1945. godine, Nastavno odeljenje Generalštaba, radi obezbeđenja planske i sistematske nastave, preduzima prve mere u odabiranju i usavršavanju kadrova. Organizuje se prvi kurs za fiskulturne rukovodioce i nastavnike fiskulture. Kurs je održan pri Državnom institutu za fiskulturu u Beogradu, u ulici Deligradskoj, od 23. oktobra do 24. novembra 1945. godine, a pohađao ga je 31 slušalac. Program kursa obuhvatao je teme iz programa trupe, koji je te 1945. godine propisalo Nastavno odeljenje Generalštaba JA (teme: „zarjadka“ (vežbe oblikovanja), rukopašni boj (borba prsa u prsa), atletika, 
vežbe na spravama i odbojka). Sve teme su izvođene praktično, a na teoretskim časovima su izučavani: metodika fizičkog vaspitanja, organizacija fizičke kulture u JA, izgradnja fiskulturnih objekata i materijalno-finansijsko obezbeđenje nastave fizičke vaspitanja i ostale sportske delatnosti. Bili su to prvi kadrovi Jugoslovenske armije koji su raspoređeni na mesta rukovodioca i nastavnika iz oblasti fizičkog vaspitanja u vojnim školama i jedinicama JA. Time su postavljeni temelji fizičke kulture u Jugoslovenskoj armiji. Nakon prvog kursa, održan je naredne 1946. godine i drugi kurs u trajanju od dva meseca, za pukovske referente za fizičko vaspitanje, a u organizaciji Generalštaba JA - Fiskulturnog odseka. Kurs je održan u Beogradu od 25. avgusta do 20. oktobra 1946. godine, a pohađala su ga 33 slušaoca [30]. Pri komandama armija održani su i kraći kursevi (nedeljni) za referente u divizijama i brigadama. Na njima su kursisti dobijali osnovna uputstva za sprovođenje plana i programa fizičkog vaspitanja (iz 1945. godine) i za organizovanje i sprovođenje sportskih takmičenja.

I ako je školovanje kadrova kroz formu kurseva bilo jedino rešenje za brži način osposobljavanja, postojala je potreba za još školovanijim kadrom, naročito za nastavnicima fizičkog vaspitanja u vojnim školama i centrima. Zato je doneta odluka da se pri Državnom institutu za fiskulturu u Beogradu, oformi Vojno odeljenje Državnog instituta za fiskulturu, 1. decembra 1947. godine (u Deligradskoj 27) pod nazivom „Jednogodišnji fiskulturni kurs [31]." Za organizaciju ovog kursa od strane JA određeni su: komandant kursa (kapetan Ivan Filipić), komesar kursa (kapetan Savo Skoko), a za nastavnike su postavljeni: vojni službenik četvrtog ranga Franjo Žic kao stariji nastavnik i potporučnik Vojo Rajnović kao nastavnik. Ostali nastavnici su bili sa DIF-a, odnosno lica iz građanstva. Školovanje je počelo 1. decembra 1947. godine, a prijemni ispit su polagala 53 oficira JA (od kojih su 4 pripadnika bili iz Narodne milicije). Za vreme školovanja slušaoci su izučavali 19 predmeta. Tako je 1. decembra 1948. godine, završila sa radom prva klasa slušalaca DIF-a. Svi oficiri su bili raspoređeni na najodgovornija mesta referenata fizičkog vaspitanja u JA.

Vojni slušaoci su bili smešteni u okviru internata Državnog instituta za fiskulturu, koji se nalazio u Deligradskoj ulici, u Beogradu. Za vreme jednogodišnjeg školovanja vojni slušaoci su izučavali i polagali 19 predmeta (Tabela 2). Po završetku školovanja najveći broj slušaoca, čak 51 od 53, bio je raspoređen na dužnosti nastavnika i rukovodioca fizičkog vaspitanja u pukovima, a manji broj u divizijama i armijama. U februaru 1948. godine otpočela je školovanje druga klasa sa 52 slušaoca.

Četvrta uprava Generalštaba JA je bila najviši organ u okviru vojske u periodu 19451950. godine, koja je rukovodila sistemom fizičkog vaspitanja u JA. U godišnjim izveštajima zabeležene su sve aktivnosti koje su se sprovodile u procesu upravljanja nastavnim oblicima sistema fizičkog vaspitanja u JA. Tu se pre svega misli na planiranje, organizovanje, rukovođenje i kontrolu u procesu obuke u sistemu fizičkog vaspitanja. Period do 1950. godine, po pitanju organizacije sistema obuke i vaspitanja u Jugoslovenskoj armiji bio je period uspona, dok je već od oktobra 1950. godine nastupio period smanjenja stručnog kadra u oblasti fizičkog vaspitanja. U komandama divizija, brigada i pukova, proces fizičke obuke sprovodili su rukovodioci za fiskulturu, do 1950. godine, kada dolazi do ukidanja formacijskih mesta. Komandiri četa i vodova su postali odgovorni i za fizičko vaspitanje i za ostalu nastavu u svojim jedinicama. U vojnim školama i učilištima, nastavom fizičkog vaspitanja rukovodili su i dalje nastavnici fizičke obuke. 
Tabela 2 - Pregled predmeta školovanja vojnog odeljenja pri DIF-u iz 1947. godine [32]

\begin{tabular}{|c|c|c|}
\hline & Naziv predmeta & fond \\
\hline 1. & Politička nastava & 370 \\
\hline 2. & Ruski jezik & 74 \\
\hline 3. & $\begin{array}{c}\text { Vojna obuka } \\
\text { (borba prsa u prsa, strojevo pravilo, naoružanje, nastava gađanja, taktika i topografija) }\end{array}$ & 215 \\
\hline 4. & Anatomija sa biomehanikom & 67 \\
\hline 5. & Fiziologija sa fiziologijom sporta & 72 \\
\hline 6. & Higijena i prva pomoć & 48 \\
\hline 7. & Pedagogika i psihologija & 39 \\
\hline 8. & Istorija fizičke kulture & 26 \\
\hline 9. & Organizacija fiskulturnog pokreta FNRJ & 20 \\
\hline 10. & Metodika fizičkog vaspitanja & 48 \\
\hline 11. & Opšte fizičko obrazovanje & 110 \\
\hline 12. & Borilački sportovi (boks 26, mačevanje 28, rvanje 20) & 74 \\
\hline 13. & Atletika & 112 \\
\hline 14. & Sportska gimnastika & 48 \\
\hline 15. & $\begin{array}{c}\text { Igre } \\
\text { (fudbal 36, odbojka 18, košarka 33, elementarne igre 18, opšte o igrama 6) }\end{array}$ & 111 \\
\hline 16. & Plivanje & 74 \\
\hline 17. & Narodne igre i plesovi & 28 \\
\hline 18. & Smučanje & 90 \\
\hline 19. & Logorovanje & 111 \\
\hline & UKUPNO & 1.737 \\
\hline
\end{tabular}

\section{Zaključak}

Na osnovu izloženih planova i programa fizičkog vaspitanja u procesu obuke JA u periodu 1945-1950. godine može se zaključiti da je oblast fizičkog vaspitanja u Jugoslovenskoj armiji predstavljala važan segment vojne obuke u navedenom periodu. Uspostavljanje i razvoj sistema fizičkog vaspitanja, kao dela opšte vojne obuke, usmeravao se ka postavljanju temelja i formiranju strukture organa za fizičko vaspitanje u JA. Izgradnja infrastrukture neophodne za realizaciju fizičkog vaspitanja za armijske potrebe i obezbeđivanje materijalno-finansijskih uslova bili su neki od ciljeva razvoja i unapređenja oblasti fizičkog vaspitanja u vojsci. Takođe, školovanje sopstvenog kadra i unapređenje sistema fizičkog vaspitanja u JA, kao i razvoj izdavačke delatnosti uslovili su i uvođenje i razvoj velikog broja nastavnih oblika fizičkog vaspitanja u sistem vojne obuke. Realizacija nastavnih oblika fizičkog vaspitanja u vojsci u navedenom periodu se sprovodila kroz planove i programe koje je izdavalo Ministarstvo odbrane i Generalštab.

Razvoj fizičkog vaspitanja u periodu posle Drugog svetskog rata je bio uslovljen promenama koje su usledile u društvu, a i u samoj Jugoslovenskoj armiji. Sagledavajući celokupan period potrebno je istaći da su se planovi i programi fizičkog vaspitanja često menjali, a samim tim i uticali na razvoj i realizaciju svakog nastavnog oblika pojedinačno, počev od uvođenja pa do ukidanja nekih nastavnih oblika. Činjenica je, da je Jugoslovenska armija u periodu po završetku Drugog svetskog rata bila oslonjena na literaturu i sistem armije SSSR-a, 
da bi uskoro pokazala potrebu za školovanjem sopstvenog kadra i oslanjanja na sopstvene resurse (formiranje Vojnog odeljenja pri DIF-u). Celokupan razvoj fizičkog vaspitanja u ovom periodu je bio uslovljen razvojem i obnovom društva i zemlje, pa je dosta truda i napora uloženo u infrastrukturu koja je bila na niskom nivou. Izgradnjom vežbališta, terena za sportske igre i stadiona sticali su se uslovi za primenu organizovanog i sistematskog vežbanja kroz nastavne oblike fizičkog vaspitanja koji su se tada primenjivali u celoj JA.

Na osnovu periodičnih izveštaja Četvrte uprave GŠ JNA, koja je bila najviši organ rukovođenja po pitanju oblasti fizičkog vaspitanja u periodu 1945-1950. godine, vršene su korekcije nastavnih oblika fizičkog vaspitanja u JA. Osnovna dokumenta kojima je bliže definisan proces obuke iz oblasti fizičkog vaspitanja u vojsci, bila su uputstva koja su se često menjala, posebno u vreme uvođenja i početnog razvijanja sistema fizičkog vaspitanja. U ovom periodu uspostavljanja sistema fizičkog vaspitanja, na snazi su bila privremena uputstva i priručnici koji nisu bili trajnijeg karaktera, već su se često menjala, pre svega zbog potreba JA da na sopstvenim iskustvima i potrebama izgradi celokupan proces obuke u vojsci. Primenom navedenih uputstava, formulisani su planovi i programi fizičkog vaspitanja, kao temelj opšte-vojne obuke. Ovi planovi i programi fizičkog vaspitanja su se periodično menjali u zavisnosti od vremenskog ograničenja obuke, namene koju je jedinica imala u sistemu vojske, odnosno dugoročnih postavljenih zadataka u odnosu na specijalnost vida, roda ili službe. Na taj način su se realizovali ciljevi u procesu obuke iz oblasti fizičkog vaspitanja, a koji su se odnosili pre svega na izgradnju odličnih fizičkih sposobnosti pripadnika vojske savladavanjem određenih kretnih znanja, veština i navika, a radi dostizanja optimalne borbene gotovosti i rešavanja vojnih zadataka u svim okolnostima.

Rezultati istraživanja su pokazali da se fizičko vaspitanje u Jugoslovenskoj armiji razvijalo kao deo opšte-vojne obuke i da je zavisilo od uzajamne veze nekoliko faktora koji su sačinjavali celokupnu strukturu i sistem fizičke obuke u periodu 1945-1950. godine: organizacija i rukovođenje; planovi i programi fizičkog vaspitanja; infrastruktura; materijalno-finansijska baza; kadrovi (školovanje i usavršavanje); nastavni oblici fizičkog vaspitanja i nastavna literatura.

\section{Literatura}

[1] Loncović, V. i Živković, A., Razvoj oružanih snaga SFRJ 1945-1995, Obuka i vaspitanje, knjiga 11, VINC, Beograd, 1986, str. 244.

[2] Isto, str. 245.

[3] Petkovski, D., Jovanović, M., Nikolovski, B., Prelević, M., Grahovac, M.. \& Knežević, B. Oružane snage Jugoslavije 1941-1981, Vojna štamparija, Beograd, 1981, str. 153-154.

[4] Ivanović, D. (1989). Razvoj oružanih snaga SFRJ 1945-1995, Savezni sekretarijat za narodnu odbranu - organizacija i nadležnost, knjiga 7, VINC. Beograd, 1989, str. 33.

[5] Ministarstvo narodne odbrane, Uputstvo za fiskulturni rad u jedinicama, Politička uprava, Beograd, 1945.

[6] Bosiljčić, S., Fizička kultura i sport u Jugoslaviji, Sportska knjiga, Beograd, 1980, str. 56.

[7] Vojni arhiv u Beogradu, Fond SSNO, kutija 279, fascikla 01, dokument 001/001, 1945.

[8] Vajić, S., Uvođenje, razvoj i realizacija organizacionih oblika fizičkog vaspitanja u Kopnenoj vojsci Jugoslovenske narodne armije u periodu 1945-1995, Fakultet sporta i fizičkog vaspitanja, magistarski rad, Beograd, 2014, str. 272. 
[9] Vojni arhiv u Beogradu, Fond SSNO, kutija 284, fascikla 01, 001/001, 1945, str. 2.

[10] Isto kao [1], str. 332.

[11] Isto, str. 255.

[12] Vojni Arhiv u Beogradu, Fond SSNO, k. 284, f. 01, d. 001/001, 1945.

[13] Vojni Arhiv u Beogradu, Fond SSNO, k. 279, f. 01, d. 004/001, 1945.

[14] Ministarstvo narodne odbrane DFJ, Plan i program za izvođenje trupne nastave $u$ jedinicama divizijske i pukovske artiljerije, VIZ, Beograd, 1945.

[15] Ministarstvo vojno i mornarice, Nastava za gimnastiku, „Davidović“, Beograd, 1920, str. 9-21, str. 24-34.

[16] Vojni Arhiv u Beogradu, Fond SSNO, k. 279, f. 02, d. 001/001, 1945.

[17] Vojni Arhiv u Beogradu, Fond SSNO, k. 279, f. 04, d. 002/001, 1946.

[18] Vojni Arhiv u Beogradu, Fond SSNO, k. 279, f. 04, d. 002/001, 1946, str. 48-61.

[19] Komanda Vazduhoplovstva JA, Plan i program borbene obuke lovačke avijacije, Vojnoizdavački zavod MNO, Beograd, 1946.

[20] Komanda Vazduhoplovstva JA, Plan i program borbene obuke jurišne avijacije, Vojnoizdavački zavod MNO, Beograd, 1946.

[21] Loncović, V. i Živković, A., Razvoj oružanih snaga SFRJ 1945-1995, Obuka i vaspitanje, knjiga 11, VINC, Beograd, 1986, str. 256.

[22] Komanda artiljerije JA, Program borbene obuke zemaljske artiljerije JA, Vojno-izdavački zavod Ministarstva narodne odbrane, Beograd, 1947.

[23] Vojni Arhiv u Beogradu, Fond SSNO, k. 280, f. 01, d. 001/001, 1947.

[24] Vojni Arhiv u Beogradu, Fond SSNO, k. 280, f. 02, d. 002/001, 1947.

[25] Jugoslovenska armija, Program borbene obuke jedinica za vezu JA, Komanda veze Jugoslovenske armije, Beograd, 1948.

[26] Vojni Arhiv u Beogradu, Fond SSNO, k. 284, f. 01, d. 001/001, 1949.

[27] Loncović, V. i Živković, A., Razvoj oružanih snaga SFRJ 1945 - 1995, Obuka i vaspitanje, knjiga 11, VINC, Beograd, 1986, str. 256.

[28] Vojni arhiv u Beogradu, Fond SSNO, K-284, fascikla 01, 001/001, 1950, str. 8.

[29] Isto, str. 8.

[30] Vojni Arhiv u Beogradu, Fond SSNO, k. 284, f. 01, d. 001/001, 1947, str. 14-16.

[31] Isto, str. 14-15.

[32] Isto, str. 14-15. 